\title{
MEMBANGUN FONDASI KEILMUAN EKONOMI ISLAM: TELAAH METODOLOGI MUHAMMAD AKRAM KHAN
}

\author{
Ahmad Ubaidillah \\ Universitas Islam Lamongan \\ e-mail: ubaidmad@yahoo.com
}

\begin{abstract}
Throughout my experience in tracking down and reading books on faith-based economics, in this case Islam, there are no books that specifically list the title of "Islamic economics". If there is, it is only initiated or introduced. Most books coming down to us still use the titles starting with the word, for example, system, concept, principle, or the doctrine of Islamic economics. Why do the authors of the book Islamic economics seem not dared to give his book title with label "science"? I presume that Islamic economics has not been considered as a science. In building a science, methodology is required. Islamic Economics also requires a well-established methodology to build the foundation of science. The study answers questions; how is methodology which is offered by Muhammad Akram Khan to build Islamic economics. The method used in this research is the study of literature with qualitative approach.The result of study concludes that Khan offers methodology of Islamic economics, if summarized, written as follows: First, Islamic economics uses a framework derived from the texts of divinity (revelation). Second, Islamic economics uses the inductive method, which gives witness to the truth or falsity assumptions and predictions about the two criteria of rationality and empirical evidence. Third, Islamic economy is built on ethical values such as justice, virtue, moderation, sacrifice, caring for others, in the analysis, as behavioral parameters. Fourth, Islamic economics is a normative discipline. Islamic Economics investigates ways and means to change the existing economy with Islamic economy. Fifth, Islamic economics ask different questions with conventional economics. Its attention is on welfare (falat) human and creating social and institutional conditions that maximize falat in society. Clearly, Islamic economics strongly supports research programs that help maximize falate. Furthermore, Khan elaborates several issues related to the methodology that often appears in the forum of Islamic economists. There are some problems that Khan proposes, they are the interaction with modern economics, the role of revelation, assuming ideal Islamic society, and the general theory of Islamic economics.
\end{abstract}

Keywords: islamic economics, methodology, Muhammad Akram Khan

\section{Pendahuluan}

Sepanjang pengalaman penulis dalam melacak dan membaca buku-buku tentang ekonomi berbasis keagamaan, dalam hal ini Islam, belum ada buku yang secara khusus mencantumkan judul "ilmu ekonomi Islam". Kalau ada, sifatnya hanya menggagas atau mengantar. Kebanyakan buku yang sampai kepada kita masih menggunakan judul yang diawali dengan kata, misalnya sistem, konsep, prinsip, atau doktrin ekonomi Islam. Mengapa penulis-penulis buku ekonomi Islam sepertinya belum berani memberikan judul bukunya dengan label "ilmu". Ini artinya bahwa ekonomi Islam belum dianggap sebagai ilmu. Dalam 
membangun sebuah ilmu, dibutuhkan metodologi. Ekonomi Islam pun demikian, ia memerlukan metodologi yang mapan untuk membangun fondasi keilmuannya.

Ekonomi Islam yang digagas sebagai sebuah disiplin ilmu baru, sebagaimana yang dituturkan oleh Nafas Furqani, ditantang untuk mampu membangun bangunan keilmuannya dengan lengkap. Ekonomi Islam diharapkan mempunyai fondasi dan basis keilmuan yang kokoh dari tradisi ilmiahnya sendiri. Sebagai sebuah ilmu, ekonomi Islam diharapkan bukan sekadar berbeda dengan ekonomi konvensional, tetapi juga mampu menjawab berbagai kelemahan yang ada dalam ilmu/sistem ekonomi terse but dengan sumber ilmiahnya sendiri. Untuk menjawab tantangan tersebut, ilmuwan ekonomi Islam menawarkan berbagai pendekatan yang mungkin ditempuh dalam membangun ekonomi Islam. Pendekatan yang diambil sangat beragam karena memang stakeholder yang terlibat dalam pengembangan ekonomi Islam juga beragam dengan latar belakang keilmuwan yang berbeda-beda. ${ }^{1}$

Dibandingkan dengan bidang lain dalam wacana ekonomi Islam, karya-karya tentang metodologi relatif masih jarang dikaji oleh ekonom-ekonom Islam. Ini merupakan salah satu kritik terhadap metodologi sebagai cara untuk merumuskan fondasi keilmuan ekonomi Islam. Dalam sebuah konferensi atau aktivitas penelitian, penekanan pada metodologi bisa dikatakan masih belum cukup memadai. Para sarjana ekonomi Islam melihat kuranganya kajian metodologis dalam ekonomi Islam sebagai satu alasan, disadari atau tidak, ketergantungan mereka pada metodologi ekonomi konvensional. Mereka melihat kelangkaan pembahasan metodologi ekonomi Islam sebagai kekurangan yang harus segara diperbaiki.

Masudul Alam Choudhury, sebagaimana yang dikutip oleh Ahmad Yousri, mengatakan bahwa ekonomi Islam telah melalaikan tujuan utamanya mengenai metodologi dan analisis, karena ekonom-ekonom Islam telah meminjam "pakaian" dari ekonomi mainstream. Oleh karena itu, ekonomi Islam saat ini tidak lain adalah kajian tentang penerapan metode ekonomi neoklasik terhadap masyarakat dan pemikiran Muslim. Sementara itu, Mohammed Aslam Haneef menghubungkan kegagalan mengembangkan bangunan keilmuan yang stabil dan metodologi yang bisa digunakan untuk mengembangkan disiplin terhadap kurangnya kajian filosofis oleh ekonom-ekonom Islam. Lebih jauh Haneef mengatakan bahwa pengabaian kajian-kajian filosofis ekonomi Islam akan menghalangi kemampuan mempromosikan mazhab-mazhab pemikiran ekonomi Islam yang masuk akal dan memperlambat perkembangkan ekonomi Islam sebagai disiplin ilmiah.

Menurut Ahmad Yousri, ekonomi Islam harus memiliki teori ekonomi otentik. Dengan kata lain, model ekonomi Islam tidak bisa diciptakan tanpa menciptakan teori yang asli. Menurutnya, teori ekonomi Islam sangat diperlukan untuk menganalisis perekonomian yang komprehensif dan memperjelas kebijakan ekonomi. Pada kenyataannya, teori dalam berbagai disiplin memainkan peranan yang sangat penting dalam pengembangan disiplin tersebut. Ekonomi Islam tidak dapat mengembangkan identitas yang unik tanpa menciptakan teori khusus yang mampu memberikan interpretasi yang bisa diterima atas fenomena yang berbeda dan menemukan sebab-sebab persoalan yang dihadapi masyarakat. ${ }^{2}$

\footnotetext{
1 Nafas Furqani, "Pembangunan Ekonomi Islam dengan Tipologi Ilmiah", Maqdis (Jurnal Kajian Ekonomi Islam), Volume 1, Nomor 1 (Januari-Juni 2016), 83.

${ }^{2}$ Ahmad Yousri, "Islamic Economics: Its Philosophy, Methodology, and Theoretical Construction.", Workshop on Basic Concepts and Thoughts in Islamic Economics, Istanbul, 2-3 March-2013.
} 
Jika sistem ekonomi Islam alternatif bisa diciptakan, ada kebutuhan, tidak hanya menciptakan teori umum, tetapi membangun ekonomi mikro dan makro Islam. Dan menurut Yousri, harus ada bangunan ekonomi Islam yang ilmiah. "Ilmu ekonomi Islam telah muncul dari dan dibangun di atas pengetahuan ekonomi Islam, yang keilmuannya dibangun dan dipasang oleh fuqaha>dan ilmuan muslim yang berminat pada aspek-aspek dan persoalan ekonomi masyarakatya"3

Yousri menyebutkan bahwa pengetahuan Islam yang ada sekarang ini tidak berasal dari al-Quran, tetapi berasal dari sarjana-sarjana muslim (ulama). Apakah pengetahuan yang dimiliki ulama benar-benar mengandung teori-teori ilmiah yang sedang kita cari? Menurut Yousri, selama ini, jawabannya adalah tidak. Tidak ada teori ilmiah yang dibangun para ulama. Tidaklah adil berharap pada ulama untuk menutupi jurang (gap) keilmuan ini, berdasarkan pada pengetahuan mereka. Ilmu ekonomi kontemporer tampaknya belum dikuasai oleh sebagian besar sarjana Islam.

Tentang evaluasi kelayakan hubungan antara ekonomi dan ajaran-ajaran Islam, Yousri mengingatkan para sarjana muslim, khususnya ahli hukum Islam. Dia mengatakan:

"Berpikir bahwa kita bisa menggantungkan secara langsung kepada syariah untuk merumuskan kebijakan ekonomi yang sukses adalah menyesatkan. Ini tidak hanya menyebabkan kegagalan dalam memecahkan persoalan ekonomi, tetapi juga akan menyulitkannya. Sebuah krisis akan muncul dan menghalangi perkembangan ekonomi Islam jika ahli hukum Islam (fuqaha berpikir bahwa mereka dapat memainkan peranan sebagai ekonom". 4

Zubair Hasan adalah ekonom Islam lainnya, yang tampaknya tidak puas dengan perkembangan ilmiah ekonomi Islam. Dia mengatakan bahwa ada persepsi yang berkembang, bahwa islamisasi pengetahuan hampir tidak menyentuh subtansinya. ${ }^{5}$ Pada kenyatannya, ekonomi Islam, atau lebih tepatnya ekonom-ekonom Islam sangat dipengaruh oleh ideologi ekonomi neoklasik atau mainstream. Bahkan, mereka telah berupaya membangun sejumlah teori Islam dengan menggunakan kriteria ekonomi neoklasik.

Timur Kuran adalah ekonom Islam lainnya yang menyoroti teori ekonomi Islam. Setelah mengajukan pertanyaan perbedaan antara ekonomi Islam dan ekonomi sekuler barat, Kuran melontarkan pertanyaan kritis apakah kita mempunyai bangunan pengetahuan ekonomi yang konsisten dan komprehensif saat ini? Kuran menjawab pertanyaan ini pertama-pertama dengan membahas konsep ekonomi Islam. Dia mengatakan:

"Karena dikembangkan untuk mencapai tujuan-tujuan politis dan kultural, ekonomi Islam tidak memenuhi standar ilmiah; koherensi, ketelitian, dan realisme. Ekonomi Islam hanya membedakan dirinya dengan tradisi intelektual lainnya dengan tujuan ingin mengganti sistem ekonomi yang ada. Oleh karena itu, kontribusi literatur ekonomi Islam secara khas dimulai dengan memperkenalkan perbedaan karakter antara perekonomian Islam dan ekonomi konvensional. Dari Mawdudi hingga sekarang, ciri

\footnotetext{
${ }^{3}$ Ahmad Yousri, "Methodological Approach to Islamic Economics", in Theoretical Foundations of Islamic Economics, in ed. H. Ahmed (Islamic Research \& Training Inst. Islamic Dev. Bank, 2002), 21.

${ }^{4}$ Ibid., $47-48$.

${ }^{5}$ Zubair Hasan, "Islamization of Knowledgein Economics: Issues and Agenda", IIUM Journal of Economics and Management, Volume 6. No. 2 (1998), 2.
} 
yang paling utama adalah larangan bunga. Dua ciri lainnya adalah zakat, sebuah sistem redistribusi Islam, dan syarat melakukan keputusan ekonomi melalaui filter moral Islam" 6

Sementara itu, Fahim Kahn mengatakan bahwa kita perlu mengembangkan teori Islam tentang ekonomi (islamic theory of economics) daripada teori ekonomi Islam (islamic economic theory). Kahn melihat ekonomi Islam saat ini mengalami kekurangan visi, metodologi, kesadaran menghubungkan antara teori dan praktik dalam aktifitas ekonomi, dukungan penelitian, komitmen kuat untuk menghasilkan karya ilmiah asli ekonomi Islam, dan kurangnya pendekatan yang holistik. ${ }^{7}$

Itulah beberapa kritik dari ekonom-ekonom Islam terkait metodologi ekonomi Islam yang masih belum mapan. Peminjaman metodologi ekonomi konvensional atau neoklasik untuk diterapkan dalam ekonomi Islam juga menjadi sasaran kritik. Pada intinya, kritik dari berbagai ekonom muslim tersebut mengindikasikan perlunya menyusun metodologi untuk membangun fondasi keilmuan ekonomi Islam. Di dalam tulisan ini, penulis akan mencoba menganalisis metodologi ekonomi Islam yang ditawarkan Muhammad Akram Khan. Apa yang dirumuskan oleh salah satu ekonom Islam terkait metodologi ekonomi Islam ini akan dijawab dalam tulisan ini.

\section{Pengertian Metodologi dan Metodologi Ekonomi}

Sebelum membahas lebih jauh gagasan metodologi Khan, perlunya dijelaskan apa sebenarnya pengertian metodologi itu. Metodologi bisa pahami sebagai bagian khusus dari cabang filsafat yang disebut dengan epistemologi. Dalam epistemologi, kita mempelajai teori pengetahuan, sumber-sumber pengetahuan, penerapan ilmu pengetahuan, dan batasan-batasan ilmu pengetahuan. Sementara metodologi, objek kajiannnya lebih spesifik, yaitu bagaimana kita mengembangkan ilmu pengetahuan (teori) dan bagaimana mengevaluasi pengetahuan (teori) yang dihasilkan.

Mark Blaug mendefinisikan metodologi ilmu ekonomi sebagai cabang ilmu ekonomi dimana kita bisa mempelajari bagaimana ekonom menyuguhkan teori-teorinya dan alasanalasan mengapa ekonom memilih teori ini bukan teori itu. Metodologi, sebagaimana didefinisikan oleh Louay Safy adalah bidang penelitian ilmiah untuk mencapai dasar kebenaran, deskripsi, penjelasan tentang aturan-aturan dan prosedur dengan metode ilmiah. Glen Fox melihat metodologi terkait dengan penilaian teori. Sementara Mohammed Aslam Haneef melihat metodologi ekonomi sebagai pembahasan dan analisis mengenai proses pembentukan model, pengembangan teori, pengujian hipotesis (bila perlu), serta penetapan dan penggunaan standar untuk mengevalusi proses tersebut. Dapatlah dikatakan bahwa metodologi berhubungan dengan standar dan tolok ukur yang menentukan sumber-sumber pernyataan ilmiah. Sementara banyak penulis ekonomi Islam membahas proses dalam istilah yang agak umum, dan tidak membahas kriteria dan prinsip untuk menilai teori dan ilmu

\footnotetext{
${ }^{6}$ Timur Kuran. Islam and Mammon: The Economic Predicaments of Islamism (Princeton: University Press, 2004), 39.

${ }^{7}$ Fahim Kahn, "Where Islamic Economics Should Generate", The Workshop on Basic Concept and Thoughts in Islamic Economics, Istambul, 2-3 March 2013, 97.
} 
pengetahuan. $^{8}$

Muhammad Akram Khan memandang bahwa metodologi secara kritis menyelidiki konsep, teori, dan prinsip-prinsip dasar penalaran terkait dengan subjek. Menurut Khan, ada perbedaan yang sangat tajam terkait metodologi ekonomi, mulai dari penekanan klasik tentang verifikasi asumsi-asumsi hingga falsifikasi neoklasik prediksi dan perbedaan tentang metodologi terkait persoalan-persoalan positif versus normatif, induktif versus deduktif, pelibatan nilai versus pengabaian nilai, preskripsi versus deskripsi, aporisme versus empirisme. Para ekonom seringkali sangat memperhatikan persoalan ini dan kerapkali mencuatkan perdebatan hangat. ${ }^{9}$

Metodologi ekonomi, menurut Zubair Hasan, secara luas terdiri dari seperangkat kriteria, aturan, dan prosedur yang disusun para filosof selama bertahun-tahun untuk menyelidiki hakikat, cakupan, dan kinerja sebuah disiplin. Metodologi termasuk dalam filsafat ekonomi yang memiliki kesamaan dengan ushul fiqih dan fiqih. ${ }^{10}$ Metodologi memberikan argumen, mungkin juga rasionalisasi, yang mendukung berbagai pilihan yang dimiliki oleh komunitas ilmiah untuk aturan dan prosedur ilmiah tertentu, termasuk menciptakan konsep, membangun teori, merumuskan hipotesis, dan menguji teori. ${ }^{11}$

Pertanyaan yang muncul adalah mengapa harus ada pembahasan tentang metodologi? Jawaban yang segara kita temukan adalah karena para ekonom sangat ingin mencapai kebenaran, dan setiap ekonom mengclaim bahwa pendekatan metodologinyalah yang mampu mencapai kebenaran tersebut dengan cara yang lebih pasti dibanding dengan metodologi lainnya. Setelah melihat dari sudut pandang ini, perdebatan terkait metodologi merupakan tuntutan manusia sejak lahir. Manusia sangat ingin mencapai kebenaran di segala zaman. AlQuran juga mengajak manusia mengikuti pesannya bahwa inilah Kitab pengetahuan yang benar. Jadi, al-Quran menyerukan naluri manusia untuk mencapai kebenaran. Al-Quran menegaskan bahwa manusia harus membuang keragu-raguan. Perdebatan tentang metodologi dalam ekonomi dan ilmu-ilmu lainnya menunjukkan bahwa hampir tidak ada ketidaksetujuan tentang persoalan ini. Semua perdebatan dimaksudkan untuk membangun aturan yang jelas dan konsisten untuk menyaring mana yang benar dan mana yang salah.

Selanjutnya, Khan juga mencatat bahwa meskipun ada perbedaan pandangan tentang metodologi, namun setidaknya ada tiga kesepakatan bersama terkait manusia. Pertama, manusia sebagian besar dikendalikan oleh kepentingan diri dan cenderung bertindak secara rasional. Kedua, kemajuan material adalah tujuan utama usaha-usaha manusia. Ketiga, manusia memiliki kecenderungan untuk memaksimalkan kesejahteraan material dan juga memiliki pengetahuan dan kemampuan memutuskan apa yang terbaik bagi mereka. ${ }^{12}$

Ketika minat utamanya adalah pengembangan dan penciptaan teori, kajian metodologi ekonomi Islam tentu saja sangat penting dan harus dilihat sebagai prasyarat utama mengembangan ilmu ekonomi Islam. Meskipun ekonomi Islam merupakan ekonomi berbasis

\footnotetext{
${ }^{8}$ Mohamed Aslam Haneef dan Hafas Furqani, "Methodologi of Islamic economics: Overview of Present State and Future Direction", International Journal of Economics, Management and Accounting, Volume 19, Nomor 1 (2011), 3 .

${ }^{9}$ Muhammad Akram Khan, An Introduction to Islamic Economics (Islamabad: International Institute of Islamic Thought, 1994), 58.

${ }^{10}$ Zubair Hasan, "Islamization of Knowledgein Economics", 16.

${ }^{11}$ Ibid., 17.

${ }^{12}$ Ibid., 58-59.
} 
agama yang berdasarkan pada al-Quran dan Sunnah sebagai sumber utama pengetahuannya, namun ekonomi Islam haruslah dilihat sebagai disiplin ilmiah yang membutuhkan metodologi ilmiah tepat yang membuat kita mampu mengembangkan teori-teori sebagai bagian dari pengembangan bangunan ilmu pengetahuan yang disebut "ilmu ekonomi Islam".

\section{Perbedaan Metodologi dan Metode}

Di atas sudah dipaparkan definisi metodologi yang dikemukakan para pakar ekonomi Islam. Selanjutnya kita perlu bertanya apa perbedaan antara metodologi dan metode? Kalau kita merujuk pada Fox, sebagaimana yang dikutip oleh Mohammed Aslam Haneef and Hafas Furqani, Fox membedakan antara metode dan metodologi. Dia mengatakan bahwa istilah metodologi secara esensial merupakan studi proses penciptaan teori yang diakui sebagai ilmiah dan ini bukan dimaksudkan menciptakan prosedur, teknik, atau pendekatan untuk permodelan. Yang terahir ini lebih tepat disebut metode. Machlup juga menjelaskan:

"Although methodology is about methods, it is not a method, nor a set of methods, nor a description of methods. Instead it provides arguments and rationalizations which support various preferences entertained by the scientific community for certain rules of intellectual procedure, including those for forming concepts, building models, formulating hypotheses, and testing theories".

Metodologi menunjukkan bukan semata-mata prosedur yang berifat teknis (teknik pemodelan) yang digunakan, pilihan kategori dan prosedur penggabungan yang diinginkan, tetapi konseptualisasi yang mendasari realitas (pandangan dunia atau worldview) yang berhubungan dengan model penalaran yang diinginkan dan juga standar yang digunakan untuk menciptakan teori. ${ }^{13}$

Dari uraian di atas dapat dikatakan bahwa metodologi adalah menganalisis proses melalui pengetahuan tentang fenomena ekonomi yang bisa dibuktikan. Metodologi secara sederhana berarti metode-metode, teknik, atau beberapa langkah prosedural yang diperlukan untuk menciptakan teori. Metodologi melampaui itu semua. Perhatiannya adalah untuk menyelidiki kriteria, rasionalisasi, argumentasi, dan justifikasi untuk penciptaan teori dan pengujian serta pembuktian reliabilitas teori tersebut.

\section{Signifikansi Metodologi Ekonomi Islam}

Selanjutnya kita bisa bertanya, apa pentingnya metodologi untuk kemajuan ilmu ekonomi Islam? Haneef dan Furqani dengan merujuk beberapa pemikir ekonomi Islam mencatat ada beberapa poin yang membuat metodologi ilmu ekonomi Islam menjadi penting. Pertama, keberhasilan perkembangan ekonomi Islam sebagai disiplin sangat bergantung pada perkembangan metodologi yang mampu memberikan arah yang jelas tentang bagaimana menghasilkan teori-teori ekonomi yang sesuai dengan doktrin ekonomi Islam. Jika kita mengatakan bahwa teori ekonomi konvensional penuh dengan visi atau nilai yang bertentangan dengan visi dan nilai-nilai Islam, maka tugas utama kita adalah menghasilkan teori ekonomi yang dijiwai dengan visi dan nilai-nilai Islam. Tanpa metodologi ekonomi Islam yang tepat, tugas ini tidak mungkin bisa dilaksanakan dengan baik.

\footnotetext{
${ }^{13}$ Mohamed Aslam Haneef dan Hafas Furqani, "Methodologi of Islamic economics”, 15.
} 
Kedua, pentingnya membahas metodologi adalah untuk menjelaskan dan menetapkan aturan, prosedur, standar, dan yang paling penting, kriteria ilmiah, yang dapat kita gunakan untuk membedakan antara yang salah dan benar dalam menciptakan dan menilai teori-teori ekonomi Islam. Hasil penyelidikan metodologi adalah seperangkat kriteria untuk penciptaan teori. Kriteria ini nantinya dapat membantu kita membedakan antara teori yang valid dan yang tidak valid. Untuk menciptakan teori, ekonomi Islam memliki kriterianya sendiri. Sumber pengetahuan tidak terbatas pada penalaran manusia dan observasi fakta. Metodologi ekonomi Islam sangat memperhatikan peranan wahyu. Keterlibatan wahyu dalam metodologi ekonomi Islam memberikan tantangan tersendiri bagi ekonomi Islam.

Ketiga, metodologi tidak hanya membahas bagaimana menciptakan teori, tetapi juga mengkaji bagaimana membuktikan kegunaan dan ketahanan uji teori dalam kehidupan nyata. Metodologi ekonomi Islam, meskipun dibangun atas dasar wahyu yang bersifat normatif, juga concern pada formulasi teori-teori yang dapat dilaksanakan dan diterapkan dalam kehidupan nyata. Terkait dengan hal ini, Choudhury menilai perlunya perumusan metodologi ekonomi Islam guna menciptakan definisi ekonomi Islam yang tepat berdasarkan pada pandangan dunia baru dan membebaskan kajian ekonomi Islam dari sifat religious-sosial tanpa isi yang dapat dikerjakan. Semetara itu Syed Nawab Haidar Naqvi menyatakan bahwa metodologi ilmu ekonomi Islam diarahkan untuk menciptakan disiplin ekonomi yang padu, berdasarkan landasan yang dapat diuji dalam masyarakat muslim yang khas atau masyarakat yang mengikuti petunjuk al-Quran, dan bukan dalam negara Islam khayalan.

Keempat, metodologi ekonomi Islam diperlukan untuk menghubungkan aspek ontologis ekonomi Islam (hakikat), yang merupakan cita-cita dan prinsip ekonomi Islam, ke aspek aksiologis (etika) yang menjadi penerapan praktis ekonomi Islam. Peranannya adalah menyatukan kedua elemen (ontologi dan aksiologi) pada tataran konseptualisasi dan aplikasinya melalui metodologi yang konsisten dan sistematis.

Kelima, metodologi ekonomi Islam bertujuan menempatkan proses okerja ilmiah ekonomi Islam sebagai disiplin, sehingga jurang ( gap) yang ada dalam kajian ekonomi Islam, sebagaimana yang istilahkan Siddiqi, Khan and Zarqa, antara mereka yang mengetahui warisan Islam namun kurang menguasai ekonomi modern di satu sisi, dan mereka yang memahami ilmu ekonomi modern namun kurang menguasai warisan Islam di sisi lain, dapat dihilangkan. ${ }^{14}$

Pada pembahasan terdahulu, penulis sudah membicarakan pengertian metodologi, metode, latar belakang pentingnya metodologi ekonomi Islam dari berbagai ekonom muslim. Pada bagian ini, secara khusus penulis akan menguraikan metodologi ekonomi Islam Muhammad Akram Khan sebagai salah satu ekonom muslim yang menuangkan banyak gagasan ekonomi Islam dalam berbagai bentuk tulisan.

\section{Metodologi Muhammad Akram Khan}

Sebagaimana yang kita ketahui, fungsi utama metodologi adalah untuk membantu manusia mencapai kebenaran. Perangkat keras (hard core) ekonomi Islam terdiri atas postulat al-Quran dan Sunnah Nabi Muhammad SAW. Postulat-postulat ini secara alamiah bersifat ketuhanan. Oleh karena itu, pertanyaan apakah postulat al-Quran dan Sunnah itu benar atau

\footnotetext{
${ }^{14}$ Ibid., 3-5.
} 
salah, tidak akan pernah muncul. Keduanya benar sejak dari sananya. Metode ekonomi Islam, pertama-tama untuk setiap keadaan, merujuk pada dua sumber ini (al-Quran dan Sunnah). Hanya setelah kita tidak menemukan petunjuk dari kedua sumber inilah nalar manusia digunakan dan persoalan metodologi muncul. ${ }^{15}$

Oleh karena itu, ekonom muslim harus memahami konsep dan pernyataan al-Quran dan Sunnah tentang ekonomi. Al-Quran memuat beberapa pernyataan tentang aspek kehidupan ekonomi. Pernyataan-pernyataan ini merupakan hukum yang difirmankan Allah. Umat Islam percaya bahwa hukum-hukum ini berjalan di kehidupan ini melalui kehendak Allah. Namun apakah hukum-hukum ini memberikan pengaruh atau efek tidak dijelaskan secara langsung oleh al-Quran. Dalam hal ini, Khan memberikan contoh beberapa ayat al-Quran:

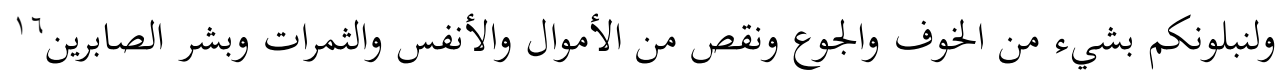

"Dan sungguh akan Kami berikan cobaan kepadamu, dengan sedikit ketakutan, kelaparan, kekurangan harta, jiwa dan buah-buahan“.

$$
\text { ولقد أخذنا آل فرعون بالسنين ونقص من الثمرات لعلهم يذكرون }
$$

"Dan sesungguhnya Kami telah menghukum (Firaun dan) kaumnya dengan (mendatangkan) musim kemarau yang panjang dan kekurangan buah-buahan, supaya mereka mengambil pelajaran“.

Ada banyak ayat lainnya yang mempunyai pesan yang sama. Ayat-ayat ini mengindikasikan bahwa kemiskinan dan kesengsaraan dianggap ujian dari Allah untuk menilai perilaku manusia dalam keadaan sengsara tersebut atau bentuk hukuman Tuhan atas dosa-dosa manusia yang lalu.

$$
\text { وأن استغفروا ربكم ثم توبوا إليه يمتعكم متاعا حسنا إلى أجل مسمى ويؤت كل ذي فضل فضله وإن تولوا فإني }
$$

"Dan hendaklah kamu meminta ampun kepada Tuhanmu dan bertobat kepada-Nya. (Jika kamu, mengerjakan yang demikian), niscaya Dia akan memberi kenikmatan yang baik (terus menerus) kepadamu sampai kepada waktu yang telah ditentukan dan Dia akan memberi kepada tiap-tiap orang yang mempunyai keutamaan (balasan) keutamaannya. Jika kamu berpaling, maka sesungguhnya aku takut kamu akan ditimpa siksa hari kiamat.

$$
\text { من كان يريد الحياة الدنيا وزينتها نوف إليهم أعمالهم فيها وهم فيها لا يبخسونج"19. }
$$

"Barang siapa yang menghendaki kehidupan dunia dan perhiasannya, niscaya Kami

15 Muhammad Akram Khan, "Methodology of Islamic Economics", dalam Syed Omar Syed Agil dan Aidit Ghazali (ed), Reading in the Concept and Methodology of Islamic Economics (Malaysia: CERT Publication, 2007), 63.

16 al-Quran, 2: 155.

${ }^{17}$ Ibid., 7: 130.

${ }^{18}$ Ibid., 11: 3 .

${ }^{19}$ Ibid., 11: 15. 
berikan kepada mereka balasan pekerjaan mereka di dunia dengan sempurna dan mereka di dunia itu tidak akan dirugikan.

Ayat-ayat di atas menjelaskan penyesalan karena menumpuk kekayaan.

Kita bisa mengambil contah lainnya dari ayat al-Quran tentang hukum kesejahteraan material dan kesengsaraan, distribusi pendapatan dan kekayaan, efek infak, dan lain sebagainya. Poin pentingnya adalah bahwa hukum etika ini merupakan pernyataan fakta namun kita tidak memahami secara tepat bagaimana hukum-hukum ini berlaku di dunia fisik. ${ }^{20}$ Fungsi sebenarnya hukum-hukum ini belum diketahui. Oleh sebab itu, kita perlu menemukannya dengan melakukan instrospeksi, eksperimen, dan dialog. Khan, menganggap inilah tugas utama bagi ekonom-ekonom muslim jika mereka ingin mengembangkan ekonomi Islam sebagai ilmu sosial yang jelas. Mereka harus mengembangkan batas-batas ilmu ekonomi dengan menemukan operasi aktual hukum ekonomi moral ini dan memperkaya pengetahuan manusia. Selanjutnya khan memberikan beberapa langka yang perlu dilakukan.

Langkah pertama. Ekonom muslim harus mengambil ayat-ayat al-Quran atau beberapa pernyataan ekonomi dalam literatur hadis sebagai sesuatu yang tetap dan tidak berubah. Manakala masing-masing ayat atau hadis yang berhubungan dengan hukum-hukum ekonomi bisa ditafsirkan lebih dari satu penafsiran, di sini kita harus memahami proses sebab akibat atau operasional ayat-ayat tersebut. Tantangan yang menghadang kita adalah saat sampai pada penafsiran yang bisa diuji atau diverifikasi secara empiris dan rasional. Menurutnya, kita tidak perlu menguji pernyataan al-Quran dan hadis. Penafsiran dan penjelasan manusia atas pernyataan-pernytaan al-Quran dan hadislah yang perlu kita uji secara empiris dan rasional untuk memahami pernyataan-peryataan tersebut.

Langkah kedua. Kita harus mengidentifikasi istilah-istilah kunci masing-masing pernyataan sebagaimana diperlihatkan dalam langkah pertama. Contohnya adalah istilah riba, zakat, infaq, al-afw, israf, tabdhir, bukhl, sadaqah, barakah, fasad fil ard, shukr, taqwa, taubah, rizq, hayat tayyiba, hasanat, dan lain sebagainya. Dengan melakukan penelitian, diskusi, brainstorming, dan pemikiran yang intensif, kita dapat mendaftar kemungkinan makna-makna dari setiap istilah menurut pemahaman kita. Makna istilah-istilah tersebut akan mengalami perubahan karena pemahaman orang lain.

Langkah ketiga. Berdasarkan pada pemahaman kita tentang istilah-istilah kunci tersebut, kita bisa mengembangkan hipotesis mengenai setiap pernyataan ekonomi dalam alQuran dan hadis. Mungkin ada beberapa hipotesis untuk setiap pernyataan dan barangkali bisa bertambah dan berkurang seiring berjalannya waktu dan pemahaman kita. Demikian pula, beberapa pernyataan al-Quran bisa melahirkan satu hipotesis saja. Kita harus membuat beberapa hipotesis dalam bentuk yang bisa diverifikasi oleh pengujian empiris maupun yang tidak bisa difalsifikasi oleh fakta-fakta dan pemikiran rasional.

Langkah keempat. Hipotesis harus terbuka untuk pengujian dan verifikasi dalam kondisi yang berubah. Hasil pengujian hipotesis harus dipublikasikan secara luas dengan mengundang masyarakat ilmiah dunia untuk menguji dan memberikan komentar atas penelitian yang

\footnotetext{
${ }^{20}$ Muhammad Akram Khan, "Methodology for Theory Building in Islamic Economic", Journal of Islamic Economics, Banking and Finance, Vol. 10, No. 2 (April - June 2014).
} 
dilakukan tersebut. ${ }^{21}$

Khan sendiri menyadari bahwa metodologi yang diusulkan bukan tanpa halangan. Ada tantangan yang akan dihadapi peneliti. Pertama, pemahaman dan penafsiran ayat-ayat alQuran dan hadis Nabi Muhammad SAW membutuhkan pengetahuan dan keahlian khusus tentang ilmu-ilmu keislaman. Namun, tantangan ini dapat diatasi dengan membentuk sebuah tim peneliti yang secara bersama-sama memiliki kompetensi, meskipun semua anggota tim mungkin tidak sepenuh menguasai bidang ini.

Kedua, pemahaman atas al-Quran dan hadis akan menghadapi persoalan dalam memisahkan yang umum dari yang khusus, dari yang duniawi dari ukhrawi, fakta-fakta dari yang metafor dan aligori, temporal dari yang universal, aturan dari yang observasi, dan lain sebagainya. Saat para ekonom mendekati al-Quran dan hadis dengan tujuan khusus menggali teori ekonomi dari pernyataan, pandangan baru akan sangat diperlukan terkait persoalan ini dan beberapa kesepakatan diperlukan sebelum memulai merumuskan hipotesis.

Ketiga, sudah disetujui secara luas oleh umat Islam bahwa petunjuk yang diberikan alQuran dan hadis adalah benar untuk sepanjang masa dan untuk semua manusia. Akan tetapi, realitas sosial senantiasa berubah, yang tentu saja membutuhkan penelitian dan peninjauan ulang atas pemahaman terdahulu teks-teks ketuhanan tersebut. Ini berarti bahwa penelitian dan peninjauan ulang teori dan hipotesis menjadi agenda penelitian yang terus-menerus.

Keempat, menemukan hubungan sebab akibat barangkali akan menemui masalah. Misalnya, muncul berbagai macam sebab untuk satu fenomena, yang salah satunya dapat menjadi sebab yang dinyatakan dalam pernyataan yang bersifat ketuhanan. Sebaliknya, mungkin akan muncul banyak akibat untuk satu sebab, yang salah satunya bisa menjadi efek yang disebutkan dalam al-Quran dan hadis. Misalnya pengeluaran zakat bisa menjadi stimulus untuk meningkatkan lapangan pekerjaan. Namun lapangan pekerjaan dapat juga dipengaruhi oleh beberapa faktor lain. Pertanyaan yang muncul adalah bagaimana kita mengukur kontribusi zakat, jika ada, kenaikan lapangan pekerjaan? Singkatnya, pertanyaan yang muncul adalah bagaimana kita mengukur hubungan sebab akibat untuk membuktikan atau tidak mensetujui hipostesis kita? Ini tentu saja akan menjadi masalah yang serius. ${ }^{22}$

\section{Peranan Akal}

Cakupan ekonomi Islam menyangkut kajian nilai-nilai Islam, analisis fenomena ekonomi nyata, dan eksplorasi cara dan alat untuk mengubah perekonomian yang ada ke dalam perekonomian Islam. Oleh karena itu, perangkat keras (hard core), dalam hal ini alQuran dan hadis, memberikan petunjuk langsung yang sangat sedikit. Bagian terbesar realitas ekonomi membutuhkan penerapan akal dan intelektualitas manusia dalam kerangka ketuhananan secara keseluruhan. Persoalan metodologi sangat terkait dengan penggunaan akal manusia. Dalam konteks ini, prinsip umumnya, jika sebuah teori tidak bertentangan dengan wahyu, maka teori tersebut terbuka untuk dikritisi. Kritisme mencakup dua bidang, yaitu rasional dan empiris. Sebuah teori harus memenuhi dua kriteria tersebut. Teori harus benar dalam pandangan rasional dan harus diperkuat dengan bukti empiris. Penyesuaian harus dicari dengan tesis falsifikasi ala Poperian. Ini mengandung makna bahwa sebuah teori akan

\footnotetext{
${ }^{21}$ Ibid., 15.

22 Ibid., 17.
} 
diuji dengan standar kemampuan dibuktikan salah (falsifiability). Teori-teori yang tidak terbukti salah (difalsifiasi) dengan dua standar tersebut, bisa diterima. Pada tingkat ini, metodologi ekonomi Islam sama dengan ilmu ekonomi.

Lebih jauh dapat dikatakan bahwa hipotesis ekonomi Islam harus dinyatakan dalam bentuk dimana hipotesis-hipotesis tersebut dalam difalsifikasi. Dengan kata lain, hipotesis harus membuat kondisi dan prediksinya menjadi jelas. Sebuah hipotesis akan dipertimbankan jika mencerikan situasi dimana hipotesis menetapkan keadaan yang akan mefalsifikannya. Dapat juga disebutkan di sini bahwa kriteria kemampuan dibuktikan salah diterapkan hanya pada dalil-dalil yang menayatakan "bagaimana" sebuah sistem ekonomi, bukan diterapkan pada pertanyaan "mengapa" sebuah sistem ekonomi karena akal hanya dapat digunakan pada pertanyaan "bagaimana". Ini tidak bisa diterapkan pada pertanyaan "'mengapa" yang mengharuskan seseorang memasuki wilayah keyakinan dan moralitas. Dalam ilmu ekonomi, persoalan yang ditanyakan adalah bagaimana pasar bekerja? Bagaimana perusahaan mengambil keputusan? Bagaimana perekonomian merespon fenomena tertentu? Dan tidak menanyakan "mengapa" karena ini akan mengakibatkan ilmu ekonomi masuk ke wilayah moralitas. Sejak Rene Descartes, filsuf Prancis, dunia Barat berusaha memisahkan akal dari keyakinan dan moralitas. Dalam ekonomi Islam, persoalan keyakinan dan moralitas keduanya valid. Oleh karena itu, untuk pertanyaan "mengapa" dapat diterapkan dalam kriteria keyakinan dan moralitas. ${ }^{23}$

\section{Penalaran Deduktif atau Induktif}

Terkait penggunaan penalaran deduktif atau induktif ini, Khan mengajukan pertanyaan apa respon ekonomi Islam terkait persoalan pilihan antara penalaran induktif dan deduktif? Pertanyaan Khan yang dijawab bukan oleh orang lain ini adalah ekonomi Islam menggunakan kedua metode tersebut. Namun, jawaban singkat ini membutuhkan kualifikasi. Umat Islam berhutang pada perkembangan penalaran induktif, dan khusnya metode empiris. Dalam ekonomi Islam, metode induktif hanya kelanjutan dari tradisi yang dikembangkan oleh umat Islam di masa lampau. Namun perlu ditegaskan di sini bahwa tidaklah mungkin menarik kesimpulan ilmiah semata-mata dengan menggunakan metode induktif. Sumber teori mungkin induktif atau a pripori, namun ekonom-ekonom Islam akan mengujinya dengan berbagai standar meliputi wahyu, akal, dan bukti empiris. Sedangkan penalaran deduktif dalam ilmu ekonomi mengasumsikan pengetahuan yang sempurna tentang masa depan oleh agen-agen ekonomi. ${ }^{24}$

\section{Asumsi dan Metode}

Dalam ekonomi Islam ada asumsi tingkat tinggi yang berasal dari wahyu dan asumsi tingkat rendah yang berdasarkan pada penalaran manusia. Asumsi tingkat tinggi tidak membutuhkan verifikasi. Sedangkan asumsi tingkat rendah perlu diuji dengan menggunakan dua kriteria, yaitu rasionalitas dan bukti-bukti empiris. Asumsi tingkat tinggi dalam ekonomi Islam. Pertama, manusia bukan manusia yang egoistis atau altruistik, melainkan keduanya. Kedua. Manusia memiliki kecenderungan bawaan untuk bersikap egoistis dan mencintai

\footnotetext{
${ }^{23}$ Muhammad Akram Khan, Methodology of Islamic Economics, 65-66.

${ }^{24}$ Muhammad Akram Khan, An Introduction to Islamic Economics, 64-65.
} 
kekayaan, namun dia juga memiliki kemampuan untuk bersikap altrusitik. Peduli dengan orang lain merupakan karakter manusia yang bisa diverifikasi dengan bukti-bukti empiris. Kedua perilaku alturistik dapat ditanamkan dan dibuat tetap dengan pendidikan. Ketiga, manusia memiliki pengetahuan masa depan yang tidak sempurna. Oleh karena itu, semua analisis ekonomi harus dilakukan dengan pandangan yang tidak pasti. Keempat, dalam analisis akhirnya, falał (kebahagiaan) di akhirat merupakan kesejahteraan di dunia ini. Asumsi tingkat tinggi lainnya dan dikembangkan berdasarkan pada ajaran-ajaran al-Quran dan hadis Nabi Muhammad. ${ }^{25}$

\section{Penyelesaian Masalah}

Khan menganggap penyelesaian masalah dalam ekonomi Islam sangat penting. Pemikiran ekonomi Islam bisa dilacak dari periode awal Islam. Pemikir-pemikir seperti Abu Yusuf, Abu Ubayd, al-Ghazali dan Ibn Taimiyah, dan lain sebagainya secara serentak telah menciptakan pendekatan dalam memecahkan masalah. Mereka semua sangat memperhatikan persoalan-persoalan ekonomi pada zamannya masing-masing. Mereka telah menulis tentang kemiskinan, keadilan sosial, perpajakan, keseimbangan ekonomi, kestidaksempurnaan pasar, dan peranan alokasi pendapatan dalam suatu negara. Oleh karena itu, menurut Khan, ekonomi Islam pada masa kita sekarang ini perlu meneruskan tradisi yang telah diciptakan oleh pemikir-pemikir muslim dahulu. Ekonom-ekonom muslim perlu mengkaji perilaku ekonomi individu, rumah tangga, perusahaan, dan negara dengan pusat perhatian. Pertama, memahami proses pembuatan keputusan dan perilaku. Kedua, menghubungkan perilaku manusia dengan kesajahteraan (fala $)$ pelaku, pekerja, dan klien, dan warga masyarakat secara keseluruhan. Dan ketiga, merumuskan hipotesis tentang strategi alternatif untuk memaksimalkan falabłdi tingkat yang berbeda. ${ }^{26}$

Khan kemudian menyimpulkan metodologi ekonomi Islam yang patut kita perhatikan bersama. Pertama, ekonomi Islam menggunakan kerangka yang berasal dari teks-teks ketuhanan (wahyu). Kerangka ini bersifat sakral dan abadi. Tidak ada seorang pun atau kelompok individu yang membuat wahyu tidak relevan. Kritik manusia tidak berlaku untuk wahyu. Inilah perbedaan dari ekonomi barat yang paradigma utamanya harus tunduk pada kritik dan mengalami perubahan. Akan tetapi penafsiran wahyu tidaklah sakral, ${ }^{27}$ dan tidak final serta tidak mutlak. ${ }^{28}$ Namun penafsiran mengikuti metodologi yang dikembangkan oleh sarjana syariah.

Kedua, ekonomi Islam lebih mengutamakan penggunaan metode induktif, yang memberikan kesaksian kebenaran atau kesalahan asumsi-asumsi dan juga prediksi tentang dua kriteria rasionalitas dan bukti empiris. Dalam ilmu ekonomi, metode deduktif lebih umum ketimbang metode induktif. Asumsi-asumsi tidak perlu harus realistis. Pengujian utama adalah bukan terletak pada kemampuan dibuktikan salah atas suatu prediksi. Asumsi dasar tentang kepentingan diri, rasionalitas, pengetahuan sempurna tentang masa depan, atau kemampuan manusia untuk mengetahui apa yang terbaik bagi dirinya, memudahkan

\footnotetext{
${ }^{25}$ Ibid., 66-67.

${ }^{26}$ Ibid., 67.

${ }^{27}$ Muhammad Akram Khan, Methodology of Islamic Economics, 71.

${ }^{28}$ Muhammad Akram Khan, An Introduction to Islamic Economcs, 70.
} 
penggunaan metode deduktif oleh ahli ekonomi. Ekonomi Islam mempunyai sikap yang berbeda tentang persoalan ini. Oleh karena itu, ekonomi Islam mengambil jalan dengan cara menggambungkan metode deduktif dan induktif dengan penekanan pada metode induktif. ${ }^{29}$

Ketiga, ekonomi Islam membangun nilai-nilai etis, seperti keadilan, kebajikan, moderasi, pengorbanan, peduli kepada yang lain, ke dalam analisis sebagai parameter perilaku. Perbincangan apakah ilmu ekonomi harus mengandung nilai adalah perdebatan yang sudah lama berlangsung. Dalam ilmu ekonomi, tidak ada ruang untuk meninggalkan pertimbangan nilai. Namun, para ekonom harus merumuskan hipotesis yang dapat dibuktikan salah. Dalam proses pengujian hipotesis, prasangka politik, sosial, dan personal pertimbangan nilai seharusnya dihilangkan. Di sinilah akan terbentang jalan menuju kemajuan ilmu ekonomi. Dalam ekonomi Islam, selama persoalan terkait dengan pilihan, prasangka personal, pendekatan ini tampaknya bisa diterima dengan kualifikasi yang memadai. Nilai-nilai etis Islam yang diberikan oleh syariah akan menjadi bagian dari teori ekonomi, dan nilai-nilai tersebut tidak akan dibuktikan salah dengan pengujian hipotesis apapun. Malahan, nilai-nilai tersebut dianggap sebagai kriteria untuk pengujian hipotesis bersama dengan data faktual. Teori yang tidak menggabungkan norma-norma etis syariah, membantahnya atau mendorong ke arah prediksi yang akan menipiskan norma-norma etis, akan ditolak dengan sendirinya meskipun tidak ada bukti-bukti empiris.

Keempat, ekonomi Islam merupakan disiplin normatif. Ekonomi Islam menyelidiki cara dan alat untuk mengubah perekonomian yang ada dengan perekonimian Islam. Ilmu ekonomi, di satu sisi, mengklaim sebagai ilmu positif, yang mengkaji fonomena ekonomi apa adanya. Ekonomi Islam bertujuan mengubah realitas ekonomi yang ada. Prediksinya juga terkait dengan perekonomian Islam yang belum ada. Oleh karena itu, pengujian aktual teori ekonomi Islam menunggu hingga perekonomian Islam menjadi kenyataan. Akan tetapi, ekonomi Islam juga memperhatikan perubahan itu sendiri. Dalil-dalil perubahannya dapat diuji dalam dunia nyata asalkan proses perubahan terjadi.

Kelima, ekonomi Islam mengajukan pertanyaan yang berbeda dengan ilmu ekonomi konvensional, perhatiannya terletak pada kesejahetaan (falak manusia dan menciptakan kondisi sosial dan institusional yang memaksimalkan falał dalam masyarakat. Jelasnya, ekonomi Islam sangat mendukung progam penelitian yang membantu memaksimalkan fala $\mathrm{A}$ \}

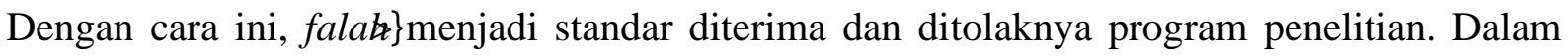
ilmu ekonomi konvensional, tidak ada krieria dalam istilah yang tidak ambigu. Akibatnya, penelitian untuk penelitian, atau ilmu pengetahuan demi ilmu pengetahuan sangat diutamakan dalam ilmu ekonomi konvensional. Dalam ekonomi Islam, semua ilmu pengetahuan mempunyai tujuan. Tujuan tersebut berasal dari pandangan dunia Islam secara keseluruhan. ${ }^{30}$

Selanjutnya, Khan mengemukkan beberapa persoalan terkait metodologi yang seringkali muncul dalam forum ekonom Islam. Ada beberapa masalah yang dikemukan Khan, yaitu interkasi dengan ilmu ekonomi modern, peranan wahyu, asumsi masyarakat Islam ideal, dan teori umum perekonomian Islam. Penulis menjelaskan keempat persoalan tersebut sebagai berikut.

\footnotetext{
${ }^{29}$ Muhammad Akram Khan, Methodology of Islamic Economics, 72.

${ }^{30}$ Ibid., 72-73.
} 


\section{Interaksi dengan Ilmu Ekonomi Modern}

Pertama-tama, Khan mengajukan pertanyaan apakah ekonomi Islam membuang sama sekali ilmu ekonomi modern dan memulainya dari awal? Tentang pertanyaan ini, Khan mengeluarkan dua pendapat. Pendapat pertama, metodologi ekonomi Barat dikembangkan dan dirancang untuk memecahkan persoalan-persoalan yang khas dengan sistemnya. Oleh karena itu, ekonomi Islam seharusnya membuang ilmu ekonomi modern dan mengembangkan teorinya sendiri dalam kerangka Islam. Pendapat kedua, ekonomi Islam tidak seharusnya mengesampingkan pemikiran ekonomi Barat yang mapan selama bertahun-tahun tersebut. Malahan, dengan kerendahan hati intelektual, kita perlu mengajukan pandangan kritis terhadap pengetahuan dan seharusnya mencoba mengindentifikasi serta mengesampingkan komponen-komponen pemikiran ini yang tidak bertentangan, baik dengan perangkat keras ekonomi Islam maupun standar empiris dan rasonal. Tentu, merupakan sikap yang sombong jika kita menolak pemikiran ekonomi modern sebagai tidak islami. Akan tetapi, kita seharusnya mengambil kriteria berikut ini untuk menilai pemikiran ekonomi Barat.

Pertama, kesesuaian dengan syariah. Kita harus menerima sebuah teori jika teori tersebut tidak bertentangan dnegan wahyu atau semangat ilahi dan tujuan-tujuan syariah (maqasid syariah). Kedua, kita harus menerima teori ekonomi modern jika teori tersebut tidak terbukti salah dengan menggunakan dua kriteria, yaitu penalaran rasional dan bukti empiris. Ketiga, kita harus menerima sebuah teori ekonomi modern jika teori itu membantu memecahkan persoalan ekonomi. Pengetahuan spekulatif yang merupakan olahraga dan latihan mental tidak diperhatikan dalam ekonomi Islam.

Pada tahap ini, kita perlu menyebutkan perangkap yang menjebak banyak ekonom muslim. Pemikiran ekonomi yang dikembangkan di Barat sangat mengutamakan akal dan ditipu oleh kebenaranya sendiri. Ekonom-ekonom muslim mencoba menafsirkan al-Quran dan Sunnah dengan cara seperti itu sebagaimana mereka mengambil pemikiran ekonomi Barat. Mereka mulai membaca penemuan-penemuan ekonom-ekonom sekuler ke dalam sumber utamanya. Ketika tidak ada batasan menafsirakan al-Quran dan Sunnah, bahaya yang muncul adalah pendekatan ini mungkin menurunkan seluruh disiplin ekonomi Islam ke dalam penghinaan, atau setidak-tidaknya ke dalam subdisiplin ekonomi Barat. Jadi, menurut Khan, tujuan utama mengembangkan ekonomi Islam akan gagal. Tidak ada aturan yang keras dan cepat untuk menyingkirkan perangkap ini kecuali ekonom-ekonom muslim harus memegang cita-citanya secara luas. Melaui kritik diri inilah ekonom-ekonom muslim dapat berhat-hati terhadap perangkap ini. ${ }^{31}$

\section{Peranan Wahyu}

Sebagaimana yang kita ketahui prinsip umum metodologi Islam adalah bahwa sebelum menggunakan referensi lainnya, kita harus merujuk pada al-Quran dan Sunnah untuk mencari petunjuk tentang berbagai persoalan. Namun, menurut Khan, ada batasan terhadap apa yang kita dapatkan dari sumber-sumber ini. Al-Quran dan Sunnah tidak menyajikan persoalanpersoalan dalam sebuah cara yang dianggap disiplin ilmiah termasuk ekonomi. Al-Quran dan Sunnah mengandung prinsip yang luas dan umum dan menyediakan kerangka dasar. Perinciannya harus dijabarkan secara lengkap oleh manusia sendiri. Namun, lanjut Khan,

\footnotetext{
${ }^{31}$ Ibid., 73-74.
} 
dalam semangat mereka, ekonom-ekonom muslim adakalanya mencoba membaca maknamakna semacam ini ke dalam ayat-ayat al-Quran yang tidak ada di sana, atau yang tidak perlu dicari dalam al-Quran karena ayat-ayat tersebut merupakan pengetahuan umum dan diperkuat dengan observasi yang sederhana. Poin penting yang ingin dikemukan Khan bahwa jika sebuah fakta dapat dipahami dan diperkuat dengan observasi dan nalar, tidak diperlukan mencari bukti dari al-Quran dan Sunnah yang seringkali dibangun dengan penafsiran yang sulit. Khan memberikan contoh, hampir tidak ada perselisihan bahwa perkerja yang kuat akan terlihat lebih produktif ketimbang pekerja yang lelah. Beberapa ekonom muslim seringkali terseret dalam teks-teks Islam, seperti ayat-ayat al-Quran dan Sunnah dan juga telah terpaksa terjebak pada penafsiran yang agak sulit terkait budak di era Islam awal untuk membuktikan persoalan ini.

Persoalan tersebut sempat membingungkan ekonom muslim karena tidak menyadari perbedaan antara "islami" dan "kerangka islami". Dengan kata "islami”, kita maksudkan dengan sesuatu yang sakral, sesuatu yang diungkapkan Tuhan dan diperintahkan oleh Nabi Muhammad SAW. "Islami" dalam pandangan ini berarti tetap. Namun, beberapa orang menambahkan kata sifat "islami" dengan konsep yang diajukan oleh manusia, misalnya keuangan islami, bank islami, bisnis islami, dan lain sebagainya. Terkadang, kata sifat "islami” tidak ditambahkan, namun pembicaraan mengindikasikan bahwa penulis atau pembicara bermasud membubuhkan kesucian terhadapnya. Ini, tentu saja, menurut Khan, perlu diklarifikasi. Semua yang terkait dengan "kerangka islami” tidak perlu islami dalam pengertian memiliki kebenaran abadi, karena ini merupakan hasil pemikiran manusia yang terbuka untuk dikaji dan diteliti. ${ }^{32}$

\section{Asumsi Masyarakat Islam Ideal}

Kebanyakan literatur ekonomi Islam mengsumsikan adanya masyarakat Islam ideal yang tidak pernah ada di tempat mana pun dan kemungkinan kehadirannya dalam waktu dekat juga sedikit. Khan lantas mengajukan pertanyaan haruskah kita meneruskan atau mempertahankan asumsi ini? Asumsi akan kehadiran masyarakat Islam ideal merupakan alat analisis yang menunjukkan hubungan hubungan ketergantungan antara cita-cita dan fenomena aktual. Teori-teori yang dinyatakan dalam kerangka ini menjelaskan bagaimana dua fenomena saling berhubungan dan faktor-faktor apa yang menyebabkan gangguan dalam hubungan ini. ${ }^{33}$

Namun, ekonom-ekonom muslim seharusnya menyadari bahwa masyarakat Islam ideal merupakan kasus khusus dalam tingkat masyarakat yang luas. Masyarakat Islam ideal mungkin bisa dicapai. Namun, perlu juga disadari bahwa realitas sosial nyata juga perlu dikaji. Ini akan membantu melepaskan romantisme yang seringkali dinikmati oleh ekonomekonom muslim sepanjang masa. Idealisme para ekonom muslim telah menyebabkan beberapa kerugian untuk kajian ekonomi Islam. Ketika analisis dirasa dalam kondisi Islam ideal, kebanyakan persoalan buruk seperti pengangguran, inflasi, dan siklus perdagangan dianggap sebagai masalah yang sedernaha. ${ }^{34}$ Persoalan-persoalan itu dianggap tidak ada. ${ }^{35}$

\footnotetext{
${ }^{32}$ Muhammad Akram Khan, An Introduction to Islamic Economcs, 72.

${ }^{33}$ Muhammad Akram Khan, Methodology of Islamic Economics, 75.

${ }^{34}$ Ibid., 76.

${ }^{35}$ Muhammad Akram Khan, An Introduction to Islamic Economcs, 73.
} 
Karena dalam perekonomian Islam ideal persoalan-persoalan itu tidak ada, ekonom-ekonom muslim cenderung merasa bahwa seseorang bahkan tidak perlu secara serius mengkajinya. Menurut Khan, pandangan ini merupakan pendekatan yang sangat simplistis. Persoalanpersoalan ini merupakan persoalan kehidupan riil dan tidak ada alasan untuk percaya bahwa persoalan-persolan tersebut tidak akan terjadi di perekonomian Islam ideal. Sangatlah mungkin bahwa umat Islam bertindak sebagaimana yang diharapkan meskipun dalam masyaraat ideal dan ini mungkin menyebabkan munculnya persoalan semacam ini. Oleh karena itu, ekonom-ekonom muslim harus menghadapi kenyataan dan membahas persoalanpersoalan kehidupan nyata. ${ }^{36}$

\section{Teori Umum Perekonomian Islam}

Ekonomi Islam berkali-kali dikritik karena tidak mempunyai teori umum perekonomian Islam. Bahkan, ditolak sebagai ekonomi yang bersifat utopis dan non-operasional. Dalam hal ini, Khan mengajukan pertanyaan apakah kritik ini adil? Teori umum perkonomian, menurut Khan, bisa muncul dari kajian keadaan kehidupan nyata. Teori, sebagaimana yang dijelaskan terdahulu, merupakan abstraksi realitas yang kompleks. Teori dimaksudkan untuk menjelaskan, menganalisis, memprediksi perilaku variabel kehidupan nyata. Secara umum disepakati bahwa ini tidak pernah ada dalam masyarakat Islam manapun di dunia ini. Bagaimana teori umum dapat dikembangkan dalam masyarakat yang tidak ada? Inilah alasan mengapa ekonom-ekonom Islam pada saat ini jarang mampu menjelaskan posisi Islam dalam persoalan ekonomi.

Dalam keadaan semacam ini, lanjut Khan, tidaklah adil menciptakan teori umum perekonomian Islam. Paling baik, menurutnya, ekonom-ekonom muslim diharapkan mampu merumuskan teori umum transisi. Namun, teori transisi merupakan masalah yang kompleks karena perekonomian dunia berbeda secara tajam dalam hal kepemilikan sumber dayanya, sistem nilai, infrastukur sosial. Akibatnya, tidak akan ada teori perubahan (transisi) yang bisa diterima secara luas. ${ }^{37}$ Kita percaya bahwa teori tansisi untuk perekonomian Islam, paling tidak teori umum perekonomian Islam, tidak akan muncul dari tingkat diskusi dan metodologi penelitian yang sedang digemari saat ini. Untuk memulai langkah penciptaan teori transisi sebagai langkah pertama, penelitian awal yang sungguh harus dilakukan. Berikut langkahlangkah yang perlu dilakukan ${ }^{38}$

Pertama, ketika negara-negara muslim ingin menerapkan prinsip-prinsip ekonom Islam ke dalam negaranya masing-masing, mereka harus memulai proses tersebut tanpa membuangbunag waktu. Pertama-tama perlu dilakukan penelitian tentang kondisi ekonomi dan sosial serta kehidupan aktual negara-negara muslim. Serangkain proyek penelitian harus disusun dalam master plan. Fokus penelitian ini harus berkaitan dengan fenomena penerapan prinsipprinsip dalam praktik aktual. Ekonom-ekonom pembangunan telah melakukan banyak penelitian tentang kondisi riil Dunia Ketiga, termasuk negara-negara muslim. Akan tetapi karya mereka tidak memadai, pada taraf tertentu, tidak relevan untuk tujuan saat ini, karena tidak berhubungan dengan kerangka Islam. Mereka menggunakan kerangka sekuler. Ini juga

\footnotetext{
36 Ibid.

${ }^{37}$ Ibid., 74.

${ }^{38}$ Ibid.
} 
tidak relevan karena menggunakan alat analisis ekonomi neoklasik yang seringkali sarat nilai dan barangkali tidak cocok untuk tujuan tersebut. Oleh karena itu, rancangan proyek penelitian ini harus dipahami sebagai pengantar pada kesadaran yang lebih baik atas kondisi kehidupan nyata negara-negara muslim.

Kedua, rangkain proyek penelitian harus secara kritis meneliti kebijakan sosial-ekonomi negara-negara muslim dari sudut pandang Islam. Ini akan memberikan kesadaran akan dampak kebijakan-kebijakan tersebut dalam penciptaan perekonomian Islam. Ketiga, perlunya meneliti lembaga pendidikan, kultural, dan sosial dan dampaknya terhadap kondisi ekonomi. Lagi-lagi, ini membutuhkan pandangan kritis dari nilai-nilai Islam. Keempat, perlunya melakukan kajian yang meliputi banyak hal tentang pola perilaku masyarakat muslim dan respon mereka terhadap ajaran-ajaran Islam. Ini akan membantu mengubah pendekatan utopis ekonomi Islam. ${ }^{39}$

\section{Kesimpulan}

Dari pembahasan di atas, dapat ditarik beberapa kesimpulan terkait metodologi ekonomi Islam. Ada beberapa alasan penting terkait perlunya membangun metodologi ekonomi Islam, di antaranya pertama, keberhasilan perkembangan ekonomi Islam sebagai disiplin sangat bergantung pada perkembangan metodologis yang mampu memberikan arah yang jelas tentang bagaimana menghasilkan teori-teori ekonomi yang sesuai dengan doktrin ekonomi Islam. Kedua, pentingnya membahas metodologi adalah untuk menjelaskan dan menetapkan aturan, prosedur, standar, dan yang paling penting, kriteria ilmiah, yang dapat kita gunakan untuk membedakan antara yang salah dan benar dalam menciptakan dan menilai teori-teori ekonomi Islam.

Ketiga, metodologi tidak hanya membahas bagaimana menciptakan teori, tetapi juga mengkaji bagaimana membuktikan kegunaan dan ketahanan uji teori dalam kehidupan nyata. Metodologi ekonomi Islam, meskipun dibangun atas dasar wahyu yang bersifat normatif, juga concern pada formulasi teori-teori yang dapat dilaksanakan dan diterapkan dalam kehidupan nyata. Keempat, metodologi ekonomi Islam diperlukan untuk menghubungkan aspek ontologis ekonomi Islam (hakikat), yang merupakan cita-cita dan prinsip ekonomi Islam, ke aspek aksiologis (etika) yang menjadi penerapan praktis ekonomi Islam. Peranannya adalah menyatukan kedua elemen (ontologi dan aksiologi) pada tataran konseptualisasi dan aplikasinya melalui metodologi yang konsisten dan sistematis.

Kelima, metodologi ekonomi Islam bertujuan menempatkan proses operasi ilmiah ekonomi Islam sebagai disiplin, sehingga jurang ( $\mathrm{gap}$ ) yang ada dalam kajian ekonomi Islam, antara mereka yang mengetahui warisan Islam namun kurang menguasai ekonomi modern di satu sisi, dan mereka yang memahami ilmu ekonomi modern namun kurang menguasai warisan Islam di sisi lain, dapat dihilangkan.

Selanjutnya Muhammad Akram Khan menawarkan rancangan metodologi ekonomi Islam yang, jika diringkas, tertulis sebagai berikut. Pertama, ekonomi Islam menggunakan kerangka yang berasal dari teks-teks ketuhanan (wahyu). Kedua, ekonomi Islam lebih mengutamakan penggunaan metode induktif, yang memberikan kesaksian kebenaran atau kesalahan asumsi-asumsi dan juga prediksi tentang dua kriteria rasionalitas dan bukti empiris.

\footnotetext{
${ }^{39}$ Ibid., 75-76.
} 
Ketiga, ekonomi Islam membangun nilai-nilai etis seperti keadilan, kebajikan, moderasi, pengorbanan, peduli kepada yang lain, ke dalam analisis sebagai parameter perilaku. Keempat, ekonomi Islam merupakan disiplin normatif. Ekonomi Islam menyelidiki cara dan alat untuk mengubah perekonomian yang ada dengan perekonimian Islam. Kelima, ekonomi Islam mengajukan pertanyaan yang berbeda dengan ilmu ekonomi konvensional, perhatiannya terletak pada kesejahteraan (falat) manusia dan menciptakan kondisi sosial dan institusional yang memaksimalkan fala łdalam masyarakat. Jelasnya, ekonomi Islam sangat mendukung progam penelitian yang membantu memaksimalkan fala . Selanjutnya, Khan mengemukakan beberapa persoalan terkait metodologi yang seringkali muncul dalam forum ekonom Islam. Ada beberapa masalah yang dikemukakan Khan, yaitu interaksi dengan ilmu ekonomi modern, peranan wahyu, asumsi masyarakat Islam ideal, dan teori umum perekonomian Islam.

\section{Daftar Rujukan}

Furqani, Nafas. "Pembangunan Ekonomi Islam dengan Tipologi Ilmiah", Maqdis (Jurnal Kajian Ekonomi Islam), Volume 1, Nomor 1 (Januari-Juni 2016).

Haneef, Mohamed Aslam dan Hafas Furqani. "Methodologi of Islamic economics: Overview of Present State dan Future Direction", International Journal of Economics, Management and Accounting, Volume 19, Nomor 1 (2011).

Hasan, Zubair. "Islamization of Knowledgein Economics: Issues and Agenda", IIUM Journal of Economics and Management, Volume 6, Nomor 2 (1998).

Kahn, Fahim. "Where Islamic Economics Should Generate", The Workshop on Basic Concept and Thoughts in Islamic Economics, Istanbul 2-3 Maret 2013.

Khan, Muhammad Akram. An Introduction to Islamic Economics. Islamabad: International Institute of Islamic Thought, 1994.

. "Methodology of Islamic Economics", dalam Syed Omar Syed Agil dan Aidit Ghazali (ed). Reading in the Concept and Methodology of Islamic Economics. Malaysia: CERT Publication, 2007.

"Methodology for Theory Building in Islamic Economic", Journal of Islamic Economics, Banking and Finance, Volume 10, Nomor 2 (April-Juni 2014).

Kuran, Timur. Islam and Mammon: The Economic Predicaments of Islamism. Princeton: University Press, 2004.

Yousri, Ahmad. "Islamic Economics: Its Philosophy, Methodology and Theoretical Construction", the Workshop on Basic Concepts and Thoughts in Islamic Economics, Istanbul 2-3 Maret 2013.

"Methodological Approach to Islamic Economics", dalam H. Ahmed (ed). Theoretical Foundations of Islamic Economics. t.tp: Islamic Development Bank, 2002. 